\title{
Upsala Journal of Medical Sciences
}

\section{The Uppsala anatomist Ivar Sandström and the parathyroid gland}

\section{Henry Johansson}

To cite this article: Henry Johansson (2015) The Uppsala anatomist Ivar Sandström and the parathyroid gland, Upsala Journal of Medical Sciences, 120:2, 72-77

To link to this article: https://doi.org/10.3109/03009734.2015.1027426

\section{() Informa Healthcare}

Published online: 27 Apr 2015.

Submit your article to this journal $\pi$

LII Article views: 377

Q View related articles $\longleftarrow$

View Crossmark data $\nearrow$

4 Citing articles: 4 View citing articles 


\title{
The Uppsala anatomist Ivar Sandström and the parathyroid gland
}

\author{
HENRY JOHANSSON \\ Department of Surgical Sciences, Uppsala University, Uppsala, Sweden
}

Key words: Anatomy, endocrinology, parathyroid gland

\section{The last anatomical discovery}

The discovery of the parathyroid gland by the Uppsala anatomist Ivar Sandström (Figure 1) is often called the last anatomical discovery. That remarkable discovery was made in 1877 at the Anatomical Department in Uppsala. At that time Sandström was a young medical student, who had worked as an assistant at the department since 1873. His discovery was published in Upsala Läkareförenings Förhandlingar, in 1880 (1). His publication was in Swedish, and the paper was entitled 'On a New Gland in Man and Several Animals'. The article comprised 30 pages, and in the introduction Sandström writes:

Almost three years ago I found on the thyroid gland of a dog a small organ, hardly as big as a hemp seed, which was enclosed in the same connective tissue as the thyroid, but could be distinguished therefrom by the light colour. Microscopically the examination revealed glandular tissue completely different from that of the thyroid (1).

Afterwards he continued his dissections and found similar glands in cats and rabbits. Stimulated by these findings he started examinations in human autopsy subjects, and in his article he writes:

The existence of a hitherto unknown gland in what has so often been a subject of anatomical examination called for a thorough approach to the region around the thyroid gland even in man. Although the probability of finding something hitherto unrecognised seemed so small that it was exclusively with the purpose of completing the investigation, rather than with the hope of finding something new, that I began a careful examination of this region. So much the greater was my astonishment therefore when in the first individual examined I found on both sides at the inferior border of the thyroid gland an organ of the size of a small pea, which, judging from its exterior did not appear to be a lymph gland, nor an accessory thyroid gland, and upon histological examination showed a rather peculiar structure (2).

The strength of his work lay in his careful dissections and examinations. The dissections included 50 autopsy cases, and in 43 of them he found four glands, two on each side of the thyroid. He presented a detailed gross description of the position, size, colour, and the various forms of the gland (Figure 2). He mentioned that the glands should be looked upon in the vicinity of the thyroid. Sometimes the glands were only $3 \mathrm{~mm}$ in diameter, in other cases up to $15 \mathrm{~mm}$. Histologically he noted that there was variable distribution between the parenchymal and fat cells. Sandström thought that the glands were embryonal remnants of the thyroid and suggested that the new structures should be named 'glandulae parathyroideae'. He was not able to allow even himself to make a guess of the possible physiological role of the glands but suggested that they could be of pathological importance and clinical relevance. Many of Sandström's epoch-making anatomical and histological observations are of interest also for modern pathology and surgery.

Correspondence: Henry Johansson, Department of Surgical Sciences, Uppsala University, Uppsala, Sweden. E-mail: henry.johansson29@gmail.com

(Received 25 February 2015; accepted 26 February 2015)

ISSN 0300-9734 print/ISSN 2000-1967 online (c) 2015 Informa Healthcare

DOI: $10.3109 / 03009734.2015 .1027426$ 


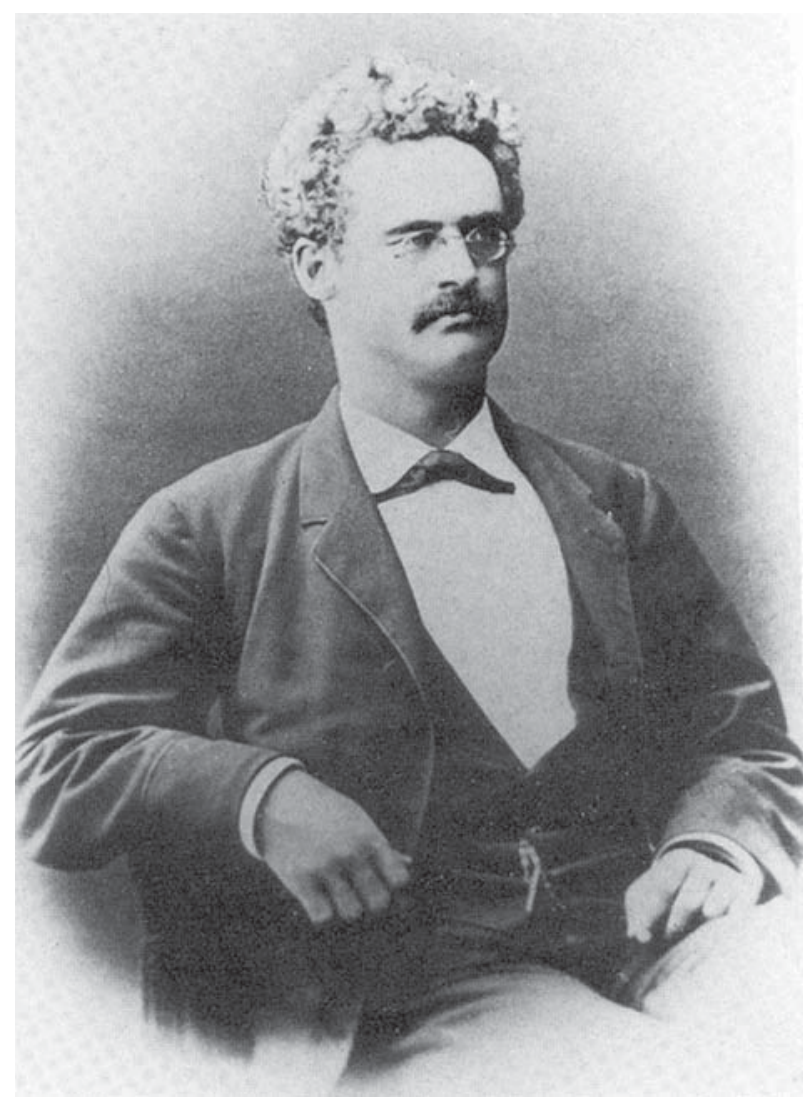

Figure 1. Ivar Sandström, 1852-1889.

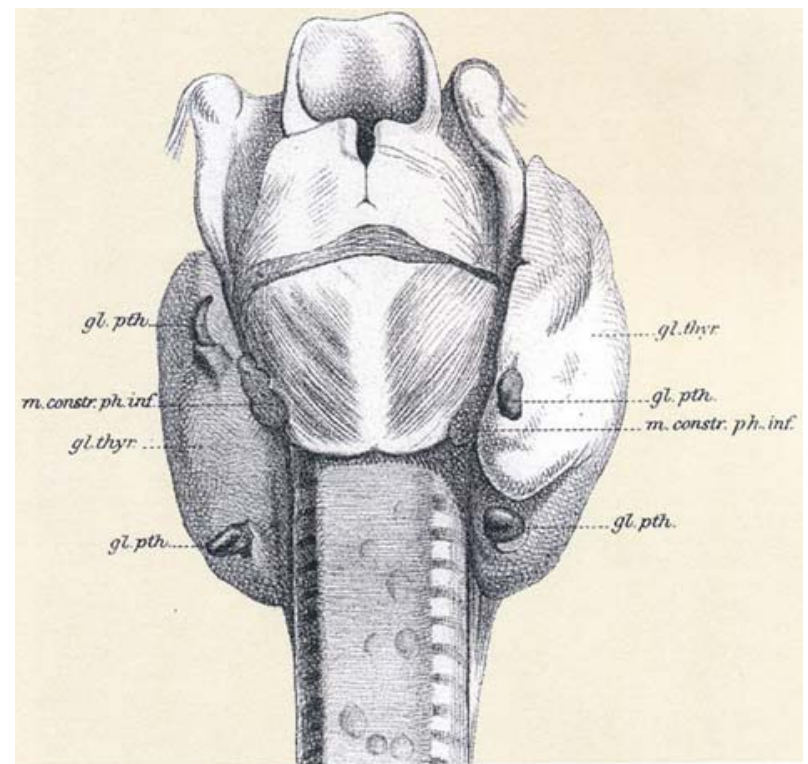

Figure 2. Drawing by Sandström of human parathyroid glandular anatomy. 


\section{No international recognition}

To obtain international recognition, Sandström translated his manuscript into German with the hope of getting the article published in Rudolf Virchow's journal, one of the most famous at that time. For Sandström it was a big disappointment when Virchow declined its publication in his journal, because of the length of the paper (30 pages). Many believe, however, that the truth was different. Virchow had himself noted some structures in the region of the thyroid and may have realized when he read Sandström's manuscript that it was the parathyroid gland he had observed $(3,4)$. He was probably not willing to give the young Swede full credit for the discovery of a new organ (5). Therefore Sandström's paper was published only in Swedish (1), and if two abstracts had not been published in a German yearbook of 1880 his work would probably have remained unrecognized for many years.

\section{The discovery of the parathyroid on a rhinoceros}

Like Virchow, prior researchers had observed structures near the thyroid in humans. They did not pay much attention to these findings; the structures were usually considered accessory glands of the thyroid. However, Sandström was not first to detect the parathyroid gland - it was the English professor of comparative anatomy Sir Richard Owen. He made the discovery in 1850 - the year of Sandström's birth — during a dissection of an Indian rhinoceros at the London Zoo. His observation was reported to the Zoological Society of London, but the paper was not published until 1862, when it appeared in the Transactions of the Society (6). In his article Owen describes the parathyroid gland as 'a small compact yellow glandular body attached to the thyroid gland at the point where the veins emerge'. Owen had probably no prior knowledge of the presence of this organ, no microscopic examination was performed, and he never mentioned such glands in other animals. Owen's anatomical finding passed unnoticed until 1905, when it was mentioned in a paper in the British Medical fournal. Therefore, the credit for the discovery of the parathyroid gland has justly been given to Ivar Sandström, who was the first to observe the gland in human and to make a thorough description microscopically.

In 1906, the American R. L. Thompson praised Sandström's discovery with the following words:

This paper of Sandström is so thorough, that little has been added to our knowledge of the anatomy or histology of these glands since their discovery and it is so complete as to leave no doubt, that he deserved all credit for the discovery of these organs (4).

\section{The man behind the discovery}

Ivar Sandström was born in Stockholm in 1852 as the fifth child in a family of seven brothers and sisters. His father was a surveyor who died of cholera when Ivar was only six years old. His mother became guardian of all the children. Facing financial difficulties, she gave up Ivar and his younger sister Anna (who became a famous teacher and pedagogue) to foster parents. After seven years in foster care Ivar returned to his family. With the economic support of his brother Nils he was able to rejoin the family and return to his studies.

In 1872 he began his medical studies at the University of Uppsala, where he became a medicine candidate in 1878. He worked as an assistant at the Department of Anatomy (Figure 3), and during 1879-80 was appointed 'prosector' at the department. In 1881, he became an extra teacher in histology and remained in this position until 1886, when he became a licensed physician at Uppsala University.

He married in 1885 and had two children. The family was poor, and Sandström had to split his time between his own medical studies, his research, and jobs that would earn money for his family. His wife became more and more distressed by his long hours and financial struggles. After a few years, she left him, taking the two children with her (7).

Sandström suffered from a hereditary mental disease and was plagued by psychiatric, alcoholic, and drug problems from a young age. Sandström was disappointed with the reception of his scientific work. His impression of the Scandinavian meeting of Natural Sciences in Stockholm in 1880 was of 'a big Scandinavian humbug'. His disillusionment is reflected in a letter to his sister, dated 8 August 1880, where he writes:

... I accepted an invitation from Stockholm to attend an international meeting of the Natural Scientists in order that I might do my part so that we Swedes should not succumb to our guests-which later on proved not to be the case at all.... One should, of course, at a personal meeting of so many men who devote themselves to science, be inclined to expect less of a hurried reading of, more or less unimportant products of genius whose creators in any case would not forget to publish them if they are of any value, than rather a friendly exchange of 


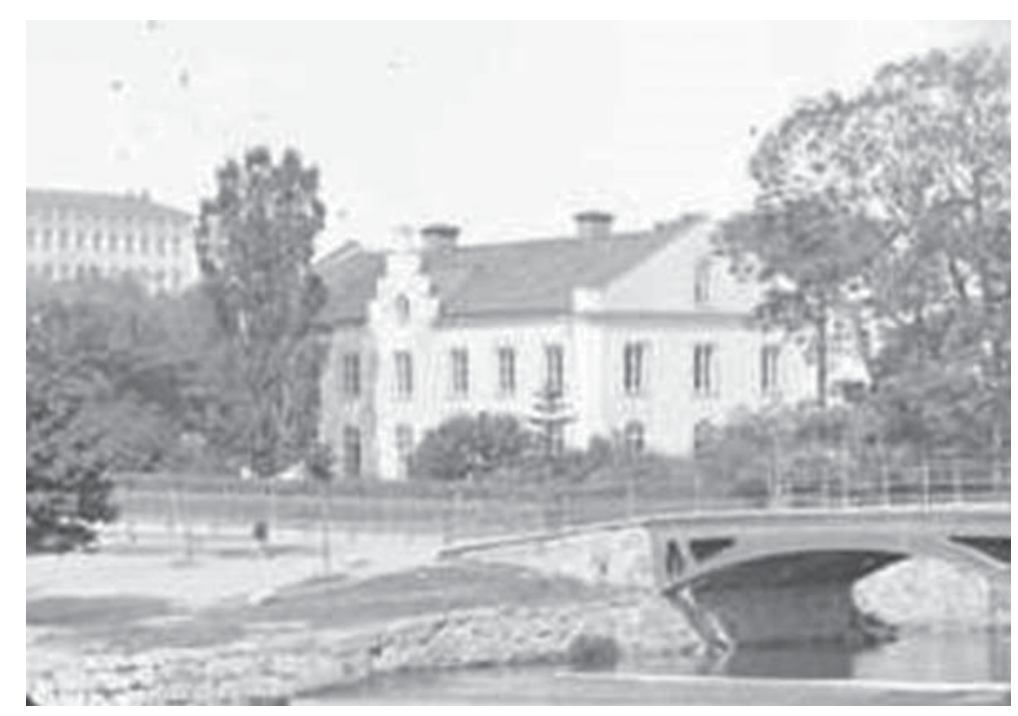

Figure 3. The building where Sandström discovered the parathyroid gland.

thoughts and of trustful communication of personal experiences and impressions. Nothing of the kind was seen ... everyone seemed to be there with the intention of showing what 'discoveries' he had made and at the same time give the astonished world the opportunity to have a look at the fortunate discoverer. But for the discovery itself, for the revealed truth, the interest was little or none.

In time, Sandström became more depressed. In 1886 he was treated for an acute psychotic episode at Ulleråker's Hospital in Uppsala. His psychiatric problems worsened, and in early 1889 his older brother Nils took care of Ivar at his home in Askesta, where he was manager for a sawmill industry. The intention was to give Ivar a quiet and calm existence, but these hopes were dashed. In June, 1889, at the age of 37 years, Ivar Sandström committed suicide. The day before, he was sitting together with Nils and his family saying 'it would have been nice to become a professor and get a name' (7). Sandström never became a professor, but his discovery has given him a name to be remembered in the medical history, and his scientific work has often been praised for its accuracy. His discovery is forever associated with his name and the department of anatomy in Uppsala.

\section{The parathyroid gland and calcium}

At the time of Sandström's discovery, the physiological function of the parathyroid gland was unknown. A decade later (in 1891) Eugéne Gley, professor of physiology in Paris, published the first report on a relationship between the parathyroid glands and tetany. In canine experiments he found that thyroidectomy was followed by tetany and death only if the parathyroids were also removed (8). Some years later (in 1896) two Italians, Giorlio Vassala and Francesco Generali, observed that tetany could be caused by parathyroidectomy alone. They hypothesized that tetany was caused by an intoxication and that the parathyroids were the organs that removed the toxins - later on believed to be guanidine - from the body. Regardless, the parathyroid glands were now recognized as vital organs to be managed with great care in thyroid surgery. Tetany was at that time a common and harmful complication to thyroid surgery.

The theory that tetany was caused by an intoxication persisted for many years. However, in 1924 it became clear through the work of William MacCollum, pathologist at Johns Hopkins Hospital, that tetany was the result of calcium deficiency. About the same time the Norwegian physiologist Harald Salvesen proved that the hypocalcemic tetany could be treated with injections of crude parathyroid extract. Further research led to the isolation of the parathyroid hormone by the Canadian professor James Collip in 1925, and it became clear that the hormone was calcium-regulating (9).

\section{The parathyroid gland and bone disease}

In 1891 the German pathologist Friedrich van Rechlinghausen described the parathyroid cystic bone disease, which was given the name 'osteitis fibrosa cystica' (10). The association between this typical bone disorder and 
parathyroid disease was established in 1904, when Max Askanazy of Tubingen, Germany, described a patient with bone changes and a parathyroid tumour (11). In 1907 Jakob Erdheim, a Viennese pathologist, reported that patients dying of advanced skeletal disease frequently exhibited enlarged parathyroid glands (12). He suggested that the enlargement of the parathyroids accompanying the bone changes was a compensatory phenomenon and that the skeletal disease should be treated with parathyroid extract. In 1915 Friedrich Schlagenhaufer questioned the validity of this interpretation. He had observed that mostly only one of the four glands was enlarged, and proposed that the changes in the parathyroid glands were the primary events leading to the bone disease (13). On these grounds it seemed logical to treat these patients by removal of the diseased gland.

\section{The first parathyroidectomy}

The first parathyroidectomy was carried out by Felix Mandl in Vienna in 1925 (14). Mandl's patient Albert Jahne was a 38-year-old trolley conductor suffering from a severe, crippling bone disease. He had fractured his femur, and his blood calcium level was very high. His disorder was recognized as a typical parathyroid bone disease. Mandl thought that the disease was due to a parathyroid deficiency, and the patient was first treated by parathyroid extract and grafted fresh parathyroid tissue. This, however, made his condition worse, and Mandl decided to explore Albert Jahne's neck surgically. The operation was performed under local anaesthesia and a parathyroid tumour measuring $21 \times 12 \times 12 \mathrm{~mm}$ was removed. The three remaining glands were normal. The result of this operation was dramatic reversal of the bone changes. Mandl had for the first time shown that Schlagenhaufer's hypothesis was correct: the bone disease was secondary to a lesion of the parathyroid gland.

News of Mandl's operation spread, and in 1931 about 20 more operations had been performed in Europe and the United States. Around 1950 several surgeons had experience with parathyroid surgery, and a decade later the number of patients receiving parathyroidectomy for hyperparathyroidism had grown. By the 1960s routine biochemical screening, including serum calcium determinations, was introduced. Since then hyperparathyroidism has been more frequently diagnosed leading to a rapid development of parathyroid surgery.

In Sweden, John Hellström, professor of surgery at the Karolinska Hospital in Stockholm, was the great pioneer of parathyroid surgery. His first operation was performed in 1930, but few patients were treated prior to 1950. In 1962 he presented his series of 138 patients. In his studies he confirmed the association between renal stones and hyperparathyroidism (15). Twenty per cent of Hellström's patients were reoperative cases, who had been operated on at other hospitals. The failed primary operation was mostly the result of an incomplete neck operation. Hellström strongly emphasized that parathyroid surgery should be carried out 'in hospitals where the services of experienced surgeons and pathologists were available' (15).

In Uppsala, the first parathyroid neck exploration was performed in 1941 on a woman with the diagnosis of 'rachitis tarda'. Only a single normal-sized gland was found, and the patient was unimproved following the operation. The first operation where an abnormal gland was identified and removed was, in fact, a reoperation undertaken in 1946 on a woman with multiple spontaneous fractures. The operation was performed by Olle Hultén, professor of surgery in Uppsala 1942-1964. The patient had previously undergone a parathyroid operation, which had failed to cure her. At the reoperation, a kidney-shaped, bean-sized adenoma was removed from the mediastinum by sternotomy. The serum calcium decreased dramatically after the operation, and the patient developed severe tetany. Despite intravenous infusion of both calcium and parathyroid hormone the patient died postoperatively.

\section{The parathyroid-an 'Uppsala' organ}

In Uppsala parathyroid surgery has held a prominent position. A hundred years after Sandström's discovery Göran Åkerström presented another unique study from the surgical department on the anatomy and histology of the parathyroid glands. His study became valuable for surgeons involved in parathyroid surgery. Along with studies of the anatomy and history of the glands, hyperparathyroidism itself has been extensively studied in Uppsala. The natural course of the disease has been examined, and it was found that an increased mortality was associated with hypercalcemia and successful surgery resulted in a better survival. In one study it was shown that as many as $65 \%-80 \%$ of patients with hyperparathyroidism had psychiatric symptoms that could be eliminated with parathyroidectomy. In some studies it has been demonstrated that even mild forms of hyperparathyroidism are associated with renal stone disease as well as disturbances of lipid and skeletal metabolism; successful surgery provides an important benefit for such patients. 
The pathogenesis of hyperparathyroidism has also been the subject of several studies in Uppsala. It has been demonstrated, for example, that defective calcium regulation can result from reduced expression of calcium receptors on the parathyroid cells. The research has also shown that the disease can be caused by a gene variant that lowers the expression of vitamin D receptors, reducing the regulatory effect of the vitamin on the secretion of parathyroid hormone. An interesting observation is that the parathyroid glands possess an enzyme that can convert vitamin $\mathrm{D}$ to its active metabolite and hence have influence on growth and hormone production. Benign parathyroid tumours - adenomas - show increased expression of this enzyme and thus inhibited growth, whereas cancers have reduced expression and thereby a more aggressive growth. In a recent study, it was found that genetic aberrations may be a common pathway to development of parathyroid tumours.

\section{Modern parathyroid surgery}

Primary hyperparathyroidism is caused by a single adenoma in $90 \%$ of cases. Today, the enlarged gland can often be localized preoperatively by using imaging techniques. This has led to a wide use of minimally invasive surgical approaches for removal of the adenomas. Conventional neck explorations are becoming rarer. Of course, such approaches are still indicated in cases when hyperplastic glands are expected, in reoperations, or when removal of a goitre is needed. Modern literature indicates that results and complication rates after a minimally invasive surgery approach is comparable to those obtained by neck exploration via standard open surgery.

Declaration of interest: The author reports no conflicts of interest. The author alone is responsible for the content and writing of the paper.

\section{References}

1. Sandström IV. On a new gland in man and several mammals - glandulae parathyroideae. Upsala Läk Förenings Förh. 1879-1880;15: 441-71.

2. Seipel CM. On a new gland in man and several mammals (glandulae parathyroideae) by Ivar Sandström (English translation). Baltimore: Johns Hopkins Press; 1938.

3. Kock W. Medicinska klassiker. V. Ivar Viktor Sandström. Svenska Läkartidningen. 1944;34:2073-82.

4. Kock W. Ivar Viktor Sandström och bisköldkörtlarna. En svensk insats i anatomiens historia. Nordisk medicinhistorisk årsbok. 1969; Suppl II:8-15.

5. Johansson H. Ivar Sandström, Uppsala-anatomen som upptäckte bisköldkörteln. Medicinhistoriska museet i Uppsala 2013. ISBN 97891-981137-1-6.

6. Owen R. On the anatomy of the Indian rhinoceros (Rh. unicornis, L). Trans Zool Soc Lond. 1862;4:31-58.

7. Ask-Upmark E, Rexed B, Sandström B. Ivar Sandstöm and the parathyroid glands. A 90-years-anniversary. Acta Univ Ups. 1967;13: 4-14.

8. Gley E. Sur les functions du corps thyroid. C R Séances Soc Biol. 1891;43:841-3.

9. Collip JP. Extraction of parathyroid hormone which will prevent or control parathyroid tetany and regulates level of blood calcium. J Biol Chem. 1925;63:395-438.

10. von Recklinghausen FD. Die fibröse oder deformierende Ostitis, die Osteomalacie und die osteoplastische Karzinose in ihren gegenseitigen Beziehungen. In Festschrift fur Rudolf Virchow Reimer. Berlin: 1891. p 1-89.

11. Askanazy M. Uber Ostitis deformans ohne ostoides Gewebe. Arb Geb Path Anat Inst Tubingen. 1903;4:398-422.

12. Erdheim J. Uber die Dentinverkalkung in Nagezahn bei der Epithelkörerchen transplantation. Frankfurt Z Path. 1911;7:295-342.

13. Schlagenhaufer F. Zwei Fälle von Parathyroideatumoren. Wien Klin Wschr. 1915;28:1362.

14. Mandl F. Therapeutischer Versuch bei Ostitis fibrosa generalisata mittels Extirpation eines Epithelkörperchentumors. Wien Klin Wschr. 1925;50:1343-4.

15. Hellström J. Primary hyperparathyroidism. Triangle. 1962;5:171-8. 